\title{
Carry-over of DNA from genetically modified soyabean and maize to cow's milk
}

\author{
M. De Giacomo', C. Di Domenicantonio, B. De Santis, F. Debegnach, R. Onori and C. Brera \\ Italian National Institute for Health, Department of Veterinary Public Health and Food Safety, GMO and Mycotoxin Unit \\ Viale Regina Elena 299, Rome, Italy
}

KEY WORDS: dairy cow, milk, GM-feed, husbandry systems, recombinant DNA, transfer

Received: 20 October 2015

Revised: 6 March 2016

Accepted: $\quad 20$ May 2016

${ }^{1}$ Corresponding author:

e-mail: marzia.degiacomo@iss.it

\begin{abstract}
The objective of this study was to evaluate the carry-over of transgenic soyabean and maize DNA in samples of milk deriving from different groups of cows fed with either genetically modified (GM) or GM-free feed. Also, to understand the possible source of such contamination of milk which can be of endogenous or exogenous origin (contamination from GM feed containing 'dust or aerosols'). The milk and feed samples were taken during routine practices of the dairy farms in order to be as close as possible to real condition. In total 66 samples of cow's milk and 120 samples of feed (GM, GM-free and organic feed) were collected in six Italian farms with different farming systems (organic and conventional) and types of barn stalls (milking area contiguous or separated from feeding station). The quantitative Real-Time PCR analysis of samples confirmed the presence of GM soya and maize in GM labeled feed and their absence in organic/GM-free feed. In the latter group, neither transgenic nor endogenous soyabean DNA was detected in the milk samples as expected. The limit of detection was estimated by spiking whole milk samples with GM plant DNA before DNA extraction. The smallest concentration of soyabean DNA required for detection was $1 \mathrm{ng} \cdot \mathrm{ml}^{-1}$ of milk for lectin gene which corresponded to about 900 copies per ml of milk. No milk samples of GM-fed cows was found suspicious for the presence of recombinant DNA within the limit of detection. This means that neither transfer of genetic material nor aerosol contamination from feed to milk can be shown in the investigated husbandry system.
\end{abstract}

\section{Introduction}

The worldwide demand for genetically modified (GM) ingredients has led to 100 -fold increase in its cultivation from 1.7 million ha in 1996 to 181.5 million ha in 2014, making the procurement of non-GM crops more expensive and difficult (James, 2014). Soya continued to be the principal biotech crop in 2014, followed by biotech maize, cotton and canola (James, 2014).
According to GMO-Compass (GMO communication and safety evaluation platform, www.gmocompass.org, 2015) the European Union Member States annually import about 40 million tons of soya and soya by-products, half of which is used as animal feed. Generally, 60 to $90 \%$ of world soya imports come from GM plants particularly from USA, Brazil and Argentina. The fact that $80 \%$ of the world's soya is now modified, makes the access to non-GM soya at a reasonable cost very difficult (Popp et al., 2013). 
In contrast, EU imports only 10 million tonnes of maize per year. Actually, EU is a major producer of maize and is quite self-sufficient; the Member States produce approximately 173 million tonnes of ensilage maize and 56 million tonnes of grain maize (GMO-Compass, 2015, www.gmo-compass. org, 2015). Small quantities of GM maize (MON 810 event) are currently being grown in Spain, Portugal, Slovakia, Czech Republic, Romania, and are mainly used in animal feeding.

Accordingly, the availability of non-GM products used as feed could be problematic in the future.

European consumers have generally expressed their concerns regarding GMO ingredients in human foods and the majority is asking for its complete elimination, some consumers go even further and demand a complete ban of GMOs in animal feed as well.

There are specific rules concerning traceability and labelling for animal feed and human food, however they do not apply to the GM-fed animal products such as meat, milk and eggs. This is a serious loophole in the law.

One of the major concerns raised by the scientific community regards the possibility that DNA introduced into GM crops could be transferred into mammalian cells or bacteria harbouring the animal gastrointestinal tract, and as a consequence might be risky for the humans as final consumers (EFSA, 2007, 2009; ADAS, 2013; Van Eenennaam and Young, 2014; MARLON PROJECT ('Monitoring of Animals for Feed-related Risks in the Long Term', FP7-KBBE-2012-6-singlestage).

Milk is also nutritional rich environment for a variety of microorganisms: both in vitro studies and experimental ecosystems have demonstrated that some of these milk bacteria are naturally transformable. As a consequence, the occurrence of bacterial uptake of plant-derived DNA is also likely in milk medium. These concerns resulted in many studies discribing the fate of plant dietary DNA in the gastrointestinal tract (GIT) and tissue of different animals - from domesticated to wild. Rizzi et al. (2012), Swiatkiewicz et al. (2014), Van Eenennaam and Young (2014) presented comprehensive reviews in this topic critically evaluating the findings and issues that have emerged from previous works. All these studies controlled feeding trials and used PCR as the primary test.

So, the objective of current study was to verify the possible presence of feed-derived DNA in organic and conventional milk by evaluating the presence of transgenic and plant DNA and assessing its endogenous or exogenous origin as a result of the carry-over from cows fed with either GM or GM-free feed and from environment (contamination from 'dust or aerosols') (Agodi et al., 2006). Although there are some other studies on this topic, this is the first study carried out in real life husbandry systems without changing the routine operations or labour management practices - no confined spaces were set and all cows were fed their usual diet.

\section{Material and methods}

\section{Farming system selection}

Six Italian dairy farms with different farming systems, but with comparable size (500 - 600 Italian Friesian cows), location (region Emilia Romagna, Italy), and number of lactation, were enrolled into the study.

Three feed types (GM, GM-free and organic) and two different housing systems were considered: stanchion barn consisting of multiple individual stalls arranged in rows and separated by alleys, closed on all sides; and open barn consisting of shelter with open space (cows can freely move or rest), usually with bedded and manure pack.

Moreover, to evaluate the possible sources of contamination, the farm systems with milking area separated or contiguous to feeding station (distance about $50-100 \mathrm{~m}$ or less than $5 \mathrm{~m}$, respectively) were selected (Table 1).

Table 1. Sampling scheme of genetically modified (GM), organic and GM-free feed (maize feed ingredient and complete feed), number of incremental samples (IS) and the target ingredient (in brackets)

\begin{tabular}{|c|c|c|c|}
\hline \multirow{2}{*}{ Farm } & GM feed & Organic feed & GM-free feed \\
\hline & \multicolumn{3}{|c|}{ number of IS } \\
\hline \multirow{2}{*}{$\begin{array}{l}\text { Farm } 1 \\
\text { Stanchion barn } \\
\text { (near) }^{*}\end{array}$} & 10 (maize) & - & - \\
\hline & 10 (maize, soya) & - & - \\
\hline \multirow{2}{*}{$\begin{array}{l}\text { Farm } 2 \\
\text { Stanchion barn } \\
\text { (far) }^{*}\end{array}$} & 10 (maize) & - & - \\
\hline & 10 (maize, soya) & - & - \\
\hline \multirow{2}{*}{$\begin{array}{l}\text { Farm } 3 \\
\text { Stanchion barn } \\
\text { (far) }^{*}\end{array}$} & - & - & 10 (maize) \\
\hline & - & - & 10 (maize, soya) \\
\hline \multirow{2}{*}{$\begin{array}{l}\text { Farm } 4 \\
\text { Open barn } \\
\text { (far) }\end{array}$} & - & 10 (maize) & - \\
\hline & - & 10 (maize, soya) & - \\
\hline \multirow{2}{*}{$\begin{array}{l}\text { Farm } 5 \\
\text { Open barn } \\
\text { (near) }^{*}\end{array}$} & 10 (maize) & - & - \\
\hline & 10 (maize, soya) & - & - \\
\hline \multirow{2}{*}{$\begin{array}{l}\text { Farm } 6 \\
\text { Open barn } \\
\text { (far) }\end{array}$} & 10 (maize) & - & - \\
\hline & 10 (maize, soya) & - & - \\
\hline
\end{tabular}

* near - farm system selected with milking area contiguous to feeding station (distance less than $5 \mathrm{~m}$ ); far - farm system selected with milking area separated from feeding station (distance about $50-100 \mathrm{~m}$ ) 


\section{Milk and feed samples}

Without interfering with the normal activity schedule in six dairy farms in the region of Emilia Romagna (Italy), 66 samples of raw cow's milk and 120 feed samples were collected. Feed samples (feed ingredient maize and complete feed) were taken according to European Commission Recommendation 2004/787/EC and collected by dynamic sampling during truck unloading. The number of increments was defined according to a lot size. All 18 feed lots were below 50 tons and 10 incremental samples from each lot were collected to obtain $5 \mathrm{~kg}$ bulk sample. The analytical sample, derived from the bulk sample after homogenization and grinding, was analysed for the presence of GM materials.

The daily feed intake consisted of forage $(9 \mathrm{~kg}$; hay $\sim 50 \%$ ) properly integrated with $14 \mathrm{~kg}$ of pelleted complete feed (maize $37 \%$, barley $10 \%$, wheat bran $15 \%$, molasses $2 \%$ ) and defatted flour from oleaginous crop (soya 20\% and sunflower 16\%). Feed was composed on a dry matter basis. At each farm, maize feed ingredient and complete feed with maize and soya were sampled (Table 1).

The milk samples were collected from 10 Friesian cows ( 5 primiparous and 5 multiparous) fed previously sampled and analysed feed lots. From each farm, 11 milk samples were collected, one directly from the bulk milk cooling tank (bulk samples) and remaining from 10 cows by hand milking (individual samples obtained at the morning milking). When collecting the bulk samples, a bucket milking system was connected to a vacuum milk-transport system transporting milk to the storage tank. The pipeline and all milk handling systems were cleaned after every milking session. Also before and after hand milking, an accurate teat-end cleansing procedure was performed to prevent aerosol and cross contamination and control the spread of mastitis organisms during milking.

\section{DNA extraction from milk sample}

Due to the high amounts of protein, calcium ions and fats in milk samples, three different DNA extraction and purification procedures were performed: 1. the cetyl trimethyl ammonium bromide (CTAB)based protocol, a cellular lysis buffer, and selective precipitation with CTAB (ISO 21571:2005), 2. the NucleoSpin ${ }^{\circledR}$ Plant II Midi / Maxi kit by MACHEREY-NAGEL (Düren, Germany) and 3. the DNeasy Plant Maxi Kit by QIAGEN (Venlo, The Netherlands). By each procedure the amount of extracted genomic DNA, DNA purity and DNA suitability for amplification were examined. The most efficient method was then chosen.
Aliquots of $10 \mathrm{ml}$ of raw milk were centrifuged for $10 \mathrm{~min}$ at $10000 \mathrm{rpm}$ to separate cream, skim and pellet. The three DNA extraction procedures were applied to all fractions. To minimize DNA degradation, all milk samples were analysed within 4 days after the milking.

The 'CTAB protocol' was used with the following modifications: the cream was pre-extracted with one volume of $\mathrm{n}$-hexane at $60{ }^{\circ} \mathrm{C}$ for $10 \mathrm{~min}$, followed by centrifugation and transferred to a new vial with supplementary CTAB and afterwards incubated at $56{ }^{\circ} \mathrm{C}$ overnight. All fractions were incubated at $56{ }^{\circ} \mathrm{C}$ overnight (Poms et al., 2001).

The commercial kits were used according to the manufacturers' recommendations.

DNA yield and purity were determined by NanoDrop $^{\mathrm{TM}}-1000$ (Celbio s.p.a., Milan, Italy). Spectrophotometric measurements were performed at wavelengths of 230, 260 and $280 \mathrm{~nm}$. Absorbance ratios at A260/A280 and A260/A230 were used to assess the detection of protein impurities or other contaminants absorbing strongly at or near $280 \mathrm{~nm}$ and impurities of organic compounds co-extracted with nucleic acids from the samples.

\section{DNA extraction from feed samples}

All feed samples were milled by centrifugal mill (The Ultra Centrifugal Mill ZM 200, sieve $0.5 \mathrm{~mm}$; Retsch, Haan, Germany). DNA was extracted according to the unmodified CTAB procedure (ISO 21571:2005). A clean-up step with silica column (PCR clean-up system; Sigma-Aldrich, St. Louis, MO, USA) was applied to the DNA extracts in which the presence of PCR inhibitors was detected.

DNA yield and purity were determined by NanoDrop $^{\mathrm{TM}}-1000$ (Celbio s.p.a., Milan, Italy). Spectrophotometric measurements were performed at wavelengths of 230, 260 and $280 \mathrm{~nm}$. All DNA samples were stored at $4{ }^{\circ} \mathrm{C}$ until analysed.

\section{Qualitative PCR assays}

To check the amplificability of the isolated DNA from milk fractions, the primers JK 302 and JK 501 (Medrano and Cordova, 1990) flanking a 350 bp fragment of the bovine kappa casein gene were used; PCR reagents and reaction conditions were as described by Medrano and Cordova (1990).

The absence of PCR inhibitors in DNA preparations from milk samples was tested using DNA extracts spiked with Certified Reference Material ERM ${ }^{\circledR}-\mathrm{BF} 410$ bk (Roundup Ready ${ }^{\mathrm{TM}}$ soyabean content $1 \mathrm{~g} \cdot \mathrm{kg}^{-1}$ ). The spiked milk extracts were analysed by PCR using two primers specifically designed to amplify a $118 \mathrm{bp}$ fragment of the soya- 
Table 2. Primers and probe sets

\begin{tabular}{|c|c|c|c|}
\hline Name and reference & Target & Amplicon size, bp & Sequence (forward primer, reverse primer, probe) \\
\hline $\begin{array}{l}\text { ssllb (maize endogeneous control) } \\
\text { (Kuribara et al., 2002) }\end{array}$ & zssllb & 151 & $\begin{array}{l}\text { 5'-CTCCCAATCCTTTGACATCTGC-3' } \\
\text { 3'-TCGATTTCTCTCTTGGTGACAGG-5' } \\
\text { 5'-FAM-AGCAAAGTCAGAGCGCTGCAATGCA-TAMRA-3' }\end{array}$ \\
\hline $\begin{array}{l}\text { MON } 810 \\
\text { (Kuribara et al., 2002) }\end{array}$ & MON 810 & 113 & $\begin{array}{l}\text { 5'-GATGCCTTCTCCCTAGTGTTGA-3' } \\
\text { 3'-GGATGCACTCGTTGATGTTTG-5' } \\
\text { 5'-FAM-AGATACCAAGCGGCCATGGACAACAA-TAMRA-3' }\end{array}$ \\
\hline $\begin{array}{l}\text { Le1n (soya endogeneous control) } \\
\text { (Kuribara et al., 2002) }\end{array}$ & Le1 & 118 & $\begin{array}{l}\text { 5'-GCCCTCTACTCCACCCCCA-3' } \\
\text { 3'-GCCCATCTGCAAGCCTTTTTT-5' } \\
\text { 5'-FAM-AGCTTCGCCGCTTCCTTCAACTTCAC-TAMRA-3' }\end{array}$ \\
\hline $\begin{array}{l}\text { RRS } \\
\text { (Kuribara et al., 2002) }\end{array}$ & RR soya & 121 & $\begin{array}{l}\text { 5'-CCTTTAGGATTTCAGCATCAGTGG-3' } \\
\text { 3'-GACTTGTCGCCGGGAATG-5' } \\
\text { 5'-FAM-CGCAACCGCCCGCAAATCC-TAMRA-3' }\end{array}$ \\
\hline $\begin{array}{l}\text { p35S } \\
\text { (Kuribara et al., 2002) }\end{array}$ & CMV p35s & 101 & $\begin{array}{l}\text { 5'-ATTGATGTGATATCTCCACTGACGT-3' } \\
\text { 3'-CCTCTCCAAATGAAATGAACTTCCT-5' } \\
\text { 5'-FAM-CCCACTATCCTTCGCAAGACCCTTCCT-TAMRA-3' }\end{array}$ \\
\hline $\begin{array}{l}\text { JK } \\
\text { (Medrano et al., 1990) }\end{array}$ & $\begin{array}{l}\text { bovine kappa casein } \\
\text { k-CN }\end{array}$ & 350 & $\begin{array}{l}\text { 5'- ATCATTTATGGCCATTCCACCAAAG-3' } \\
\text { 3'- AGA CAA TGT CTC TTC CGC TTT ACC CG-5' }\end{array}$ \\
\hline
\end{tabular}

bean lectin gene Le1 as described by Kuribara et al. (2002). The PCR analyses were performed on ABI PRISM 7700 Sequence Detector (Applied Biosystems, Foster City, CA, USA - Sequence Detection System SDS 1.9.1). The absence of PCR inhibitory compounds in the DNA preparations from feed was verified by Real-Time PCR (lectine system) on four fold serial dilutions of the DNA extracts (inhibition run) and assessed according to the well-established approach validated by the European Union Reference Laboratory for GM Food and Feed (EURLGMFF) (ENGL, 2015).

The detection limit of soyabean DNA sequences in DNA extracted from milk was evaluated by RealTime PCR, with milk samples added 10, 5, 1 and $0.1 \mathrm{ng}$ of soyabean $\mathrm{ERM}^{\circledR}$-BF410bk DNA per ml of raw milk. At each level, the analysis was performed with six replicates.

To reduce the number of analyses and facilitate the identification of GM events present in the feed samples, the multi-target tool, known as the prespotted plates, was utilized as a screening method. These plates are plastic supports, where primers and probes, deriving from the validated methods specific for all the GM event authorized in EU, are predispensed in individual wells, so that only the DNA sample and the universal PCR master mix need to be added. PCR reagents and reaction conditions were as described by Querci et al. (2009).

\section{Quantitative PCR assays}

Quantification of transgenic DNA was performed by Real-Time PCR using an ABI PRISM 7700 (Applied Biosystems, Foster City, CA, USA - Sequence Detection System SDS 1.9.1) with TaqMan chemistry for both milk and feed samples; all primers and probes were synthesized by Eurogentec (Liège, Belgium).

The analytical method (Kuribara et al., 2002) was a Real-Time PCR simplex, construct-specific method. This method has been optimized for RealTime PCR instruments using plasmids (with five concentration levels in copy numbers) as reference molecule and a calibrator to detect and determine the GM amount (Table 2) calculated from relative copy numbers between the GM specific and taxon specific DNA sequences. The reaction solution $(25 \mu \mathrm{l})$ contained: $5 \mu \mathrm{l}$ DNA $\left(40-100 \mathrm{ng} \cdot \mu^{-1}\right)$, $12.5 \mu 1$ Universal Master Mix (Eurogentec, Seraing, Liège, Belgium), $0.5 \mu \mathrm{M}$ primerpair, and $0.2 \mu \mathrm{M}$ probe $(0.1 \mu \mathrm{M}$ only for $\mathrm{p} 35 \mathrm{~S})$. The PCR programme consisted of an initial decontamination of $2 \mathrm{~min}$ at $50{ }^{\circ} \mathrm{C}$, followed by $10 \mathrm{~min}$ at $95{ }^{\circ} \mathrm{C}$ and finally 40 cycles of $30 \mathrm{~s}$ at $95^{\circ} \mathrm{C}$ and $1 \mathrm{~min}$ at $59^{\circ} \mathrm{C}$.

The absolute detection limit of the PCR analysis was also calculated by serial dilutions of 20 plasmid copies according to guidelines provided by The European Union Reference Laboratory for GM Food $\&$ Feed (EU-RL GMFF) (ENGL, 2015). The obtained 
results were within the range of 5 - 10 copies for all targets. Duplicate extraction was performed on each sample and each DNA extract was analysed in triplicate.

\section{Results}

\section{Feed samples}

The extraction method used for feed ('CTAB protocol') provided a sufficient amount of DNA with satisfactory purity (A260/A280 within the range of $1.8-2.0$ and $\mathrm{A} 260 / \mathrm{A} 230>2.0)$. The concentration of DNA extracts was in the range of $90-350 \mathrm{ng} \cdot \mu \mathrm{l}^{-1}$.

Based on the screening (pre-spotted plates) results, only soyabean MON 40.3.2 and maize MON 810 were detected in the feed samples. The $\%$ of GM content was in the range of $70-90 \%$ both for soyabean MON 40.3.2 and maize MON 810. For organic and GM-free feed, the \% of GM content was below the detection limit for MON 810 and in the range of $0.01-0.3 \%$ (limit of detection, LOD) for MON 40.3.2. Values were below the labelling threshold $(0.9 \%)$, as it was expected.

\section{Milk samples}

Firstly, the best fitted method for DNA extraction from milk samples was selected. The selection was based on the three performance criteria that should be fulfilled before DNA extracts can be accepted: 1. DNA concentration higher than the working concentration stated in the applied detection method, 2. DNA of sufficient length in order to be amplified by PCR, and 3. the absence of any PCR inhibitors in the DNA extracts (ENGL, 2015).

Among the three analysed methods of DNA extraction from milk and milk fractions (cream, skim and pellet), the 'modified' CTAB based protocol (Poms et al., 2001) was the most efficient in recovering acceptable-quality DNA with exclusion of the DNA solution obtained from raw milk that frequently showed values non-compliant with the performance criteria of DNA quality (Table 3 ).

The absence of PCR inhibitors and the amplificability of DNA extracted from cream, skim and pellet fractions were tested and verified. Exception was raw milk where, despite the high yield of DNA, the absence of the amplification of an endogenous control indicates the presence of inhibitors (data not shown). According to the obtained results, it was decided to analyse only the three milk fractions.

The LOD for the lectin gene, evaluated with Real-Time PCR, was $1 \mathrm{ng}$ of soyabean DNA per ml
Table 3. Comparison of three DNA extraction methods used to measure the concentration of extracted DNA (mean \pm standard deviation; $n=6$ ) and DNA purity measured spectrophotometrically at 230, 260 and $280 \mathrm{~nm}$

\begin{tabular}{llcll}
\hline $\begin{array}{llll}\text { Extraction } \\
\text { method }\end{array}$ & $\begin{array}{l}\text { Milk } \\
\text { fraction }\end{array}$ & $\begin{array}{c}\text { DNA concentra- } \\
\text { tion, } n \cdot \mu^{-1}\end{array}$ & \multicolumn{2}{l}{ Absorbance ratio } \\
\cline { 4 - 5 } CTAB & cream & $52 \pm 19$ & 1.76 & 1.31 \\
& skim & $50 \pm 13$ & 1.92 & 2.53 \\
& pellet & $140 \pm 10$ & 1.89 & 2.26 \\
NucleoSpin $^{\circledR}$ & cream & $15 \pm 8$ & 1.33 & 0.43 \\
Plant II & skim & $20 \pm 7$ & 1.42 & 0.56 \\
& pellet & $31 \pm 10$ & 1.45 & 0.48 \\
DNeasy Plant & cream & $17 \pm 8$ & 1.53 & 0.48 \\
Maxi Kit & skim & $19 \pm 6$ & 1.38 & 0.52 \\
& pellet & $29 \pm 5$ & 1.57 & 0.63 \\
\hline
\end{tabular}

Table 4. Detection of soyabean DNA by Real-Time PCR method in DNA extracted from raw milk samples spiked with 0.1 - 10 ng of soyabean DNA (ERM ${ }^{\circledR}-B F 410 b k$ ) per $\mathrm{ml}$ of raw milk (number of positives per six extracts for each fractions)

\begin{tabular}{llll}
\hline ng of DNA added & \multicolumn{2}{l}{ Milk fraction } \\
\cline { 2 - 4 } per ml of raw milk & cream & skim & pellet \\
\hline 10 & $6 / 6$ & $6 / 6$ & $6 / 6$ \\
5 & $6 / 6$ & $6 / 6$ & $6 / 6$ \\
1 & $6 / 6$ & $2 / 6$ & $3 / 6$ \\
0.1 & $1 / 6$ & $0 / 6$ & $0 / 6$ \\
\hline
\end{tabular}

of milk for samples extracted from cream (897 copies $\cdot \mathrm{ml}^{-1}$ ) and $5 \mathrm{ng}$ soyabean DNA $\cdot \mathrm{ml}^{-1}$ of milk for samples extracted from skim and pellet (4484 copies $\cdot \mathrm{ml}^{-1}$ ) (Table 4$)$. The genomic equivalents were calculated considering that one haploid soyabean genome corresponds to a molecular weight of 1115 pg (Arumuganathan and Earle, 1991). Positive signals with $0.1 \mathrm{ng}$ DNA per ml were obtained only for one of six samples of cream.

Neither transgenic (CMV p35S, MON 810 and RRS) nor endogenous soyabean and maize (zssIlb and Le1) DNA were detected by quantitative RealTime PCR from all cow's milk samples; all samples were below the limit of detection.

\section{Discussion}

This study is in line with many other research studies where the uptake of recombinant DNA from GM plant to naturally occurring bacterial or host cells in the mammals' gastrointestinal tract has not been irrefutably demonstrated.

Despite difficulties to provide realistic DNA intake estimation for farm animals diets, it has been calculated that the DNA content of most food crops is lower than $0.02 \%$. For a $600 \mathrm{~kg}$ dairy cow, fed (dry matter basis) $40 \%$ silage and $20 \%$ grain GM 
maize as ingredients (i.e. $60 \%$ of total ration), the transgenic DNA consumption would amount to $2.6 \mathrm{mg}$ per day that represents $0.00042 \%$ of the total dietary DNA intake (Beever and Kemp, 2000). Considering that ensiling and other processes, such as heat treatment, lead to degradation of large plant DNA fragments, the actual total transgenic DNA intake may be lower. Therefore, the real exposure is likely to be lower and is biased by factors affecting dietary DNA stability.

In studies on animals fed genetically modified soya, maize and cottonseed, transgenic plant DNA has not been detected in eggs, milk and blood, even if DNA fragment of multi-copy chloroplast genes could have been detected in milk (Rizzi et al., 2012). Nevertheless, due to its higher abundance within the plant genome (500 to 5000-fold higher than in chromosomally located gene) this gene can be more simply detectable and therefore not suitable for control or comparison (Jennings et al., 2003). In conflict with the majority of studies in this field, a latter study showed that small DNA fragments can be detected in goat milk and also in organs of offspring when mother is fed GM soya (Tudisco et al., 2010). Furthermore, small fragments of transgenic DNA were also detected in milk samples from the Italian market (Agodi et al., 2006), though the authors interpreted their presence as an indicator of faecal or airborne contamination with feed particles.

Since fragments of plant DNA can be present in milk, as a result of transfer from the gastrointestinal tract into the blood or as a consequence of milk contamination during sample collection (airborne contamination with feed dust in barns), this experimental study was planned considering the latter source of contamination, and also different farming systems with milking area near (less than $5 \mathrm{~m}$ ) and far $(50-100 \mathrm{~m})$ from feeding station. Considering the LOD measured for each milk fraction, our data show that GM and plant DNA fragments, after digestion and secretion, were not detected in milk from cows reared on both GM and GM-free feed. Moreover, concerning this study, and according to the limit of detection of the method, we can exclude the aerosol contamination of milk due to GM feed particles, even in presence of $90 \%$ GM feed in the milking area.

Generally, the absence of observable events such as DNA uptake in natural systems might be due to limited exposure level and/or resident time of the DNA in the gastrointestinal tract, but in a real life husbandry system as ours, we might exclude this issue (Nordgård, 2009).
In addition, milk is a composite food with an abundance of potential PCR inhibitors (Rossen et al., 1992), and rather high number of somatic cells and bacterial flora which can cause problems in the detection of low levels of target DNA.

Considering the above, there is still a number of knowledge gaps on the persistence and fate of DNA ingested (lack of testing standardization, widely varying study designs and more sensitive analytical methods) that could result in new hypotheses and studies.

\section{Conclusions}

The obtained results exclude aerosol contamination of milk by exogenous DNA, and its carryover after digestion and secretion. This is connected with above mentioned limitations and the fact that the study was carried out in real life husbandry system without changing the routine operations (e.g., diet) and labour management practices (e.g., no confined spaces).

In connection with the fact that DNA of GM feed in milk is not detectable or consistently quantifiable, traceability represents the only source of information regarding the quality, the quantity and the origin of the feed used. In particular, the documentary traceability is essential for the production of food with protected designation of origin (PDO) and protected geographical indication (PGI).

\section{References}

ADAS, 2013. Review of the strategies for the comprehensive food and feed safety and nutritional assessment of GM plants per se. EFSA Supporting publication 2013:EN-480, pp. 115 (http:// www.efsa.europa.eu/en/supporting/doc/480e.pdf)

Agodi A., Barchitta M., Grillo A., Sciacca S., 2006. Detection of genetically modified DNA sequences in milk from the Italian market. Int. J. Hyg. Environ. Health 209, 81-88

Arumuganathan K., Earle E.D., 1991. Nuclear DNA content of some important plant species. Plant Mol. Biol. Rep. 9, 208-218

Beever D.E.,Kemp C.F., 2000. Safety issues associated with the DNA in animal feed derived from genetically modified crops. A review of scientific and regulatory procedures. Nutr. Abstr. Rev. Ser. B 70, 175-182

EFSA, 2007. Statement on the fate of recombinant DNA or proteins in meat, milk and eggs from animals fed with GM feed. EFSA J. doi:10.2903/j.efsa.2007.744

EFSA, 2009. Consolidated presentation of the joint Scientific Opinion of the GMO and BIOHAZ Panels on the 'Use of Antibiotic Resistance Genes as Marker Genes in Genetically Modified Plants' and the Scientific Opinion of the GMO Panel on 'Consequences of the Opinion on the Use of Antibiotic Resistance Genes as Marker Genes in Genetically Modified Plants on Previous EFSA Assessments of Individual GM Plants' [1]. EFSA J. doi:10.2903/j.efsa.2009.1108 
ENGL (European Network of GMO Laboratories), 2015. JRC Technical Report. Definition of Minimum Performance Requirements for Analytical Methods of GMO Testing. Joint Research Centre. Ispra (Italy), pp. 24 (http://gmo-crl.jrc.ec.europa.eu/docl MPR\%20Report\%20Application\%2020_10_2015.pdf)

European Commission, 2004. Commission Recommendation 2004/787/ EC of 4 October 2004 on technical guidance for sampling and detection of genetically modified organisms and material produced from genetically modified organisms as or in products in the context of Regulation (EC) No 1830/2003. Off. J. EU L348, 18-26

GMO-Compass webpage, retrieved August 2015 from http://www.gmocompass.org/eng/grocery_shopping/crops/18.genetically_ modified_maize_eu.html

ISO 21571:2005 Foodstuffs: Methods of analysis for the detection of genetically modified organisms and derived products: Nucleic acid extraction

James C., 2014. Global Status of Commercialized Biotech/GM Crops: 2014. ISAAA Brief No. 49. ISAAA: Ithaca, NY (USA)

Jennings J.C., Kolwyck D.C., Kays S.B., Whetsell A.J., Surber J.B., Cromwell G.L., Lirette R.P., Glenn K.C., 2003. Determining whether transgenic and endogenous plant DNA and transgenic protein are detectable in muscle from swine fed Roundup Ready soybean meal. J. Anim. Sci. 81, 1447-1455

Kuribara H., Shindo Y., Matsuoka T. et al., 2002. Novel reference molecules for quantitation of genetically modified maize and soybean. J. AOAC Int. 85, 1077-1089

MARLON PROJECT 'Monitoring of Animals for Feed-related Risks in the Long Term' FP7-KBBE; Retrieved 25 January 2016 from http:// www.marlon-project.eu/about.html\#sthash.xawjzEa1.dpuf; http://www.marlon-project.eu/index.html\#sthash.gMVbUqNo. dpuf

Medrano J.F., Cordova E.-A., 1990. Genotyping of bovine kappacasein loci following DNA sequence amplification. Nat. Biotechnol. 8, 144-146
Nordgård L., 2009. Survival and uptake of feed-derived DNA in the mammalian intestinal tract. PhD Thesis, Faculty of Medicine, University of Troms $\varnothing$ (Norway)

Poms R.E., Glössl J., Foissy H., 2001. Increased sensitivity for detection of specific target DNA in milk by concentration in milk fat. Eur. Food Res. Technol. 213, 361-365

Popp J., Pető K., Magda R., Lakner Z., 2013. Economic impact of GM hysteria on EU feed market. Am. J. Plant Sci. 4, 1547-1553

Querci M., Foti N., Bogni B., Kluga L., Broll H., Van den Eede G., 2009. Real-Time PCR based ready-to-use multi-target analytical system for GMO detection. Food Anal. Methods 2, 325-336

Rizzi A., Raddadi N., Sorlini C., Nordgrd L., Nielsen K.M., Daffonchio D., 2012. The stability and degradation of dietary DNA in the gastrointestinal tract of mammals: Implications for horizontal gene transfer and the biosafety of GMOs. Crit. Rev. Food Sci. Nutr. 52, 142-161

Rossen L., Nørskov P., Holmstrøm K., Rasmussen O.F., 1992. Inhibition of PCR by components of food samples, microbial diagnostic assays and DNA-extraction solutions. Int. J. Food Microbiol. 17, 37-45

Swiatkiewicz S., Swiatkiewicz M., Arczewska-Wlosek A., Jozefiak D., 2014. Genetically modified feeds and their effect on the metabolic parameters of food-producing animals: A review of recent studies. Anim. Feed Sci. Tech. 198, 1-19

Tudisco R., Mastellone V., Cutrignelli M.I., Lombardi P., Bovera F., Mirabella N., Piccolo G., Calabrò S., Avallone L.,Infascelli F., 2010. Fate of transgenic DNA and evaluation of metabolic effects in goats fed genetically modified and in their offsprings. Animal 4, 1662-1671

Van Eenennaam A.L., Young A.E., 2014. Prevalence and impacts of genetically engineered feedstuffs on livestock populations. J. Anim. Sci. 92, 4255-4278 